\title{
PENCIPTAAN TOKOH SEDANG DALAM NASKAH TERDAMPAR (NA PELNYM MORZU) KARYA SLAWOMIR MROZEK TERJEMAHAN A. KASIM AHMAD
}

\author{
Muhammad Banyu Bening \\ Institut Seni Indonesia Yogyakarta
}

\begin{abstract}
Abstrak: Terdampar adalah naskah drama absurd bertemakan eksistensialisme karya Slawomir Mrozek terjemahan A. Kasim Ahmad. Naskah drama absurd memberikan tantangan yang berbeda dalam perwujudan realitas dan penjiwaan aktor yang memerankannya. Tantangan ini menjadi pokok permasalahan yang akan diatasi dalam proses pembuatan tokoh Sedang. Penelitian ini bertujuan untuk menjabarkan pemeranan tokoh Sedang dengan metode keaktoran Brecht. Hasil menunjukkan bahwa kepiawaian seorang aktor dinilai dari keberhasilannya merealisasikan realitas meskipun realitas tersebut bersifat semu seperti dalam drama absurd ini.
\end{abstract}

Kata Kunci: Realitas, Manusia, Aktor, Eksistensi

\begin{abstract}
Terdampar (Stranded) is an absurd play script with existentialism theme by Slamowir Mrozek, translated by A. Kasim Ahmad. This absurd play script gives a different challenge due to its absurdist reality and difficulty for the actors to get fully immersed on their roles. These challenges become the main problem that will be solved through this paper's breakdown on Sedang character creation. This research aims to explain how Sedang characterization is done through Brecht's method. The result shows how an actor's capability is judged from his successful deliverance in realizing an absurd or vague reality like one presented in this absurd drama.
\end{abstract}

Key Words: Reality, human, Actor, Existence

\section{Pendahuluan}

Manusia adalah sebuah objek penelitian yang tidak pernah habis apabila dipelajari. Selayaknya lautan, manusia adalah lautan yang sangat luas. Bukan hanya perkara pikirannya, akan tetapi juga persoalan hatinya. Banyak sekali pisau bedah yang bisa digunakan untuk membedah lautan pikiran dan perasaan manusia itu sendiri. Jika diibaratkan perjalanan, lautan pikiran dan hati adalah perjalanan yang tidak akan menemui ujungnya. Hal ini lah yang kemudian membuat manusia menjadi sebuah objek yang menarik untuk ditelusuri dan dipelajari. Karena pada dasarnya setiap pikiran manusia itu sendiri tidak akan pernah sama, maka proses mempelajarinya akan terus berkembang.

Salah satu yang mampu menjadi pisau bedah untuk manusia itu sendiri adalah seorang aktor. Aktor merupakan bagian yang paling penting dalam pertunjukan. Seorang aktor dalam sebuah pertunjukan teater memang memiliki posisi sentral. Meskipun, semua yang terlibat dalam pertunjukan teater juga memiliki posisi sama pentingnya. Akan tetapi, aktor lebih memiliki porsi yang cukup besar karena ia adalah "pengantar pesan" dari pertunjukan tersebut. Suyatna Anirun dalam bukunya Menjadi Aktor mengatakan; "Yang menjadi media cipta dalam seni drama adalah manusia atau sekelompok manusia yang 
berkreasi dalam suatu kerja ensamble" (Anirun, 1998). Karena itulah teater bisa menjadi salah satu pisau bedah untuk membedah lautan pikir dan rasa manusia itu sendiri.

Kemudian ketika kita hendak berbicara mengenai acting, Rikrik El Saptaria dalam bukunya yang berjudul Acting Handbook, menjelaskan bahwa acting berasal dari kata "to act" yang berarti beraksi. Akting dalam konteks ini adalah perpaduan antara atraksi fisikal (kebertubuhan), intelektual (analisis karakter dan naskah) dan spiritual (transformasi jiwa) (Saptaria, 2006). Untuk menjadi seorang "pengantar pesan" yang handal, seorang aktor haruslah memiliki kesiapan yang lebih dari cukup. Kesiapan tersebut meliputi kesiapan tubuh, suara, dan jiwa.

Dalam naskah yang memiliki judul asli Na Pelnym Morzu karya Slawomir Mrozek yang diterjemahkan sebelumnya ke bahasa Inggris oleh Nicholas Bethel dengan judul Out of Sea baru kemudian diterjemahkan kembali ke bahasa Indonesia oleh A. Kasim Ahmad dengan judul Terdampar ini memiliki ruang yang sangat luas bagi seorang aktor untuk memainkan tiga kesiapan aktor tersebut.

Naskah Terdampar ini merupakan sebuah naskah absurd yang membicarakan tentang keadaan masyarakat Polandia pada tahun 1960 yang sedang mengalami pergolakan politik. Naskah ini menceritakan tentang tiga orang yang terdampar di atas sebuah gundukan karang di tengah lautan lepas. Naskah yang ditulis pada tahun 1960 ini adalah sebuah naskah yang berisi gagasan-gagasan dari Slawomir mengenai pergolakan politik yang terjadi di Polandia antara tahun 1956-1961, puncaknya terjadi pada tahun 1961. Apabila mengutip dari tulisan Bakdi Soemanto tentang teater absurd, ia berkata bahwa "Istilah teater absurd digunakan antara lain oleh Martin Esslin untuk jenis teater yang mengungkapkan kegagalan bahasa sebagai alat komunikasi" (Soemanto, 2002). Apabila disimpulkan, maka kekuatan dari teater absurd sendiri ada pada peristiwanya. Hal itu terdapat dalam naskah Terdampar ini. Selain itu, tiga tokoh utama yang ada di dalam naskah ini masing-masing mewakili suatu kaum. Tokoh Gendut mewakili orangorang berkedudukan tinggi. Tokoh Sedang mewakili orang-orang yang cerdik, licik dan mencari aman serta merupakan antek dari kaum borjuis. Tokoh Kurus mewakili rakyat bawah yang selalu tertindas dengan segala keputusan orang-orang elit.

Slawomir Mrozek menyajikan naskah ini pada penonton dengan sudut pandangnya yang tidak berada di salah satu dari ketiga tokoh itu. Hal tersebut didukung dengan posisi Slawomir yang pernah bekerja sebagai wartawan di Polandia pada masa itu. Slawomir tidak berdiri di pihak kaum Stalin yang merupakan ideologi awal bangsa Polandia dan juga tidak berdiri pada ideologi Demokrasi Parlementer yang diperjuangkan waktu itu. Slawomir berusaha memunculkan sudut pandang lain dengan bertindak sebagai orang yang berada di luar lingkaran peristiwa besar itu. Ia menyajikan potretpotret keadaan Polandia 1960an.

Perihal yang menjadi pertimbangan dalam pemilihan tokoh Sedang ialah; tokoh Sedang memiliki tantangan tersendiri yang tidak bisa dianggap remeh. Pertama, tiga tokoh ini, jika dihitung berdasar kemunculan di atas panggung memiliki porsi yang sama. Kedua, dilihat dari sisi porsi dialog, Sedang memiliki porsi dialog yang jauh lebih sedikit. Akan tetapi ia selalu hadir dalam peristiwa di atas panggung. Ketiga, tokoh Sedang ini berada di posisi antara yang berarti, ia memiliki kedekatan dengan kedua tokoh yang lain. Tokoh Sedang ini harus selalu terlihat seperti memihak pada Kurus, pada beberapa kesempatan, dan memihak pada Gendut, di beberapa kesempatan yang lain. Karena itulah ia mesti memiliki sikap- 
sikap yang cerdik dan licik untuk tetap tidak dimakan tapi tidak menolak secara frontal tentang ide makan memakan. Keempat, di dalam naskah Terdampar terdapat sebuah adegan dimana tokoh Sedang memainkan musik dengan menggunakan alat-alat dapur. Dalam adegan ini, yang dibutuhkan selain keterampilan dasar seorang aktor adalah keahlian untuk bermain dengan pisau dan berbagai macam alat dapur yang lain. Alat dapu rini dimainkan dengan presisi yang tepat sehingga membentuk musik. Seperti apa yang disampaikan oleh Djohan dalalm buku Psikologi Musik bahwa; "Setiap masyarakat memiliki apa yang disebut dengan musik, oleh karenanya semua warga masyarakan adalah potret dari kehidupan musikal" (Djohan, 2009). Dari penjelasan di atas bisa disimpulkan bahwa musik tidak melulu soal libretto yang rumit, not balok yang membingungkan, dan nada yang tersusun secara rapi dan enak didengar. Permainan menggunakan alat dapur yang menghasilkan bunyi yang indah pun bisa disebut musikal. Secara garis besar, karena empat hal itulah tokoh ini memiliki tantangannya sendiri. Tentu saja hal tersebut adalah tentang bagaimana menghidupkan tokoh yang hanya melakukan laku tanpa bicara, akan tetapi tetap hadir dalam peristiwa dan memunculkan laku cerdik dan liciknya yang bisa terus-terusan memposisikan dirinya pada keadaan aman.

Alat aktor adalah tubuh/raga dan jiwa/sukma-nya. Itulah yang harus terus menerus diasah dan dilatih agar siap dalam menghadapi, menggali, dan memainkan peran (Riantiarno, 2011). Karena itulah mempersiapkan modal utama aktor sangat dibutuhkan untuk bisa memainkan tokoh Sedang. Selain itu, pertunjukan Terdampar ini hendak dibawakan dengan bentuk Drama Musikal. Kemampuan dasar aktor sangat dibutuhkan, bukan hanya bagaimana cara untuk menyanyi indah, akan tetapi bagaimana menyanyi sesuai dengan peristiwa dan perasaan yang sedang dialami.

Dalam sebuah pertunjukan, naskah yang berjenis absurd bisa dibawakan dalam bentuk apapun. Di dalam literatur mana pun tentang absurd, tidak ada pakem mengenai bentuk pertunjukan absurd. Selain itu, di dalam drama musikal pun, tidak ada ketentuan tentang naskah seperti apa yang mesti dibawakan. Roland Barthes sendiri berkata; "Teks befungsi sebagai aktivitas transgresif yang memisahkan pengarang sebagai suatu pusat, pembatas, dan penentu kebenaran, suara dan makna (Barthes, 1981: 31). Itu artinya penulis telah mati. Naskah yang sudah berada di tangan pencipta, maka sepenuhnya menjadi hak penciptanya untuk membuat pertunjukan dari naskah tersebut. Tentunya tidak meninggalkan esensi dari naskah itu sendiri. Hanya saja, mengenai perkara bentuk absurd atau pun genre naskah yang lain, bisa dibawakan dengan bentuk apa saja, dengan catatan bahwa esensi dan pesan yang berada di dalam naskah tidak ditinggalkan.

Berdasarkan latar belakang yang sudah dijelaskan dari tokoh Sedang dalam naskah Terdampar karya Slawomir Mrozek ini, akhirnya mendapatkan rumusan penciptaan sebagai berikut;

1. Bagaimana menciptakan tokoh Sedang sebagai orang yang cerdas, licik dan pintar memutar balikkan logika sehingga ia bisa membuat posisinya selalu aman?

2. Bagaimana mewujudkan tokoh Sedang dalam pertunjukan Terdampar? berikut:

Tujuan Penciptaan adalah sebagai

1. Memahami dan mewujudkan tokoh Sedang dalam pementasan.

2. Mewujudkan tokoh Sedang secara utuh dalam naskah Terdampar.

\section{Landasan Teori}

Agar mampu mewujudkan tokoh Sedang dalam naskah Terdampar ini, 
menggunakan teori dari Bertold Brecht karena di dalam memainkan tokoh Sedang terdapat acting, menyanyi, dan menari yang sengaja dilakukan oleh aktor dan sengaja ditunjukkan pada penonton sebagai efek alienasi. Seperti yang diungkapan Ludwik Flaszen dalam Shomit Mitter (2002) tentang alienasi, "Alienasi berisikan titik balik objek yang seseorang harus menyadarinya dari sesuatu yang biasa, akrab, diperoleh langsung, kepada sesuatu yang khusus, menggetarkan dan tak terduga. Sebelum keakraban berubah menjadi kesadaran, akrab harus dihilangkan dari kemapanannya, kita harus berhenti memperkirakan bahwa objek yang ditanyakan tidak memerlukan kejelasan".

\section{Metode Penciptaan}

Dalam menciptakan tokoh Sedang ini ada tiga hal yang harus mesti disasar. Tiga hal itu merupakan modal awal dari aktor yakni tubuh, suara dan rasa. Tubuh dan suara dalam hal ini kemampuan untuk bernyanyi jelas sangat diperlukan, lalu rasa mendukung dua hal tersebut sehingga lengkaplah tiga unsur dari aktor itu sendiri. Untuk mencapai tujuan tersebut maka diperlukan beberapa langkah sebagai berikut;

\section{Analisis Penokohan}

Setiap tokoh itu hadir bukan seketika hadir. Akan tetapi ia memiliki sebab kenapa ia bisa muncul. Tiga dimensi tokoh yakni fisiologis, sosiologis, dan psikologis ini lah yang kemudian menjadi langkah selanjutnya dalam memainkan sebuah tokoh setelah pelatihan tiga modal aktor itu sudah dilakukan. Analisis ini dilakukan agar aktor yang sudah siap tubuh, vokal, dan rasa, siap memainkan tokoh tersebut secara utuh. Analisis tokoh juga merupakan metode yang sekarang menjadi familiar dengan keseluruhan proses belajar keaktoran itu sendiri (Stanislavski, 1981).

\section{Melatih Tubuh}

Tubuh merupakan perangkat paling penting dari seorang aktor. Karena di dalam tubuh ini terdapat banyak perangkat yang bisa mendukung permainannya sebagai seorang tokoh, mulai dari vokal, kecerdasan, hingga yang paling abstrak yakni rasa. Latihan tubuh merupakan latihan paling dasar yang mestinya dikuasai oleh setiap aktor sebelum ia masuk dalam dunia keaktoran lebih dalam. Tapi, banyak juga aktor yang luput dan melupakan hal dasar sehingga ketika ia bermain, tubuh yang dimilikinya tidak memiliki kesiapan sepenuhnya. Latihan-latihan tubuh dimaksudkan supaya aktor memiliki fisik yang prima dan sehat karena kesehatan adalah syarat utama bagi seorang aktor sebelum mencipta peran. Latihan olah tubuh adalah suatu proses pemerdekaan (Anirun, 1998).

Bekerja dengan tubuh bukanlah sesuatu yang aktor kerjakan dengan mudah untuk kesehatan, atau memperbaiki pertunjukan mereka. Jika kamu terbiasa mengeksplorasi tubuh dengan teratur maka tubuh menjadi sangat bebas dan terbuka, mentalmu juga berproses menjadi lentur. Lagipula, kehidupan perasaan akan menjadi lebih kaya (Oida, 2012).

Lalu ada satu adegan dalam naskah Terdampar ini dimana Sedang memainkan alat masaknya dan hasil dari suara yang didapatkan adalah suara musik yang ritmis. Hal semacam ini tentu saja perlu dilatihkan. Karena Sedang yang merupakan seorang ahli masak terutama memasak daging, memiliki keahlian untuk memainkan pisaupisau miliknya. Selain itu, aktor yang memainkan tokoh ini, juga mesti paham tentang bagaimana caranya menghasilkan musik yang ritmis dari benda yang notabene bukan alat musik.

Di dalam pelatihan olah tubuh ini juga mencakup pelatihan ekspresi. Ekspresi artinya "mendorong keluar" secara alamiah, 
baik itu perasaan atau ide secara khas. Aktivitas ekspresi merupakan bagian dari pikiran dan perasaaan kita (Saptaria, 2006). Latihan ekspresi merupakan latihan yang sangat penting bagi seorang aktor. Seperti apa yang dijelaskan oleh Saptaria di atas bahwa ekspresi merupakan bagian dari pikiran dan perasaan dan karena ekspresi menjadi semacam media untuk menyampaikan apa yang dipikirkan dan dirasakan oleh tokoh tersebut, maka media tersebut mestilah siap. Pelatihan isometrik dan topeng karakter bisa dilakukan untuk membuat otot wajah lebih peka, lentur, dan juga membuat aktor menjadi lebih kreatif dalam memunculkan emosi yang dirasakan.

3. Melatih Vokal

Melatih vokal dalam proses menciptakan tokoh Sedang ini dibagi menjadi tiga. Pertama adalah vokal untuk bernyanyi, kedua untuk berdialog, dan yang ketiga untuk menyanyikan dialog. Maksud dari menyanyikan dialog ini adalah bukan terkesan menyanyi, akan tetapi nada dan irama serta tempo yang diucapkan si aktor masih menyatu dengan musiknya. Jelas bahwa untuk melatih hal-hal tersebut harus melalui latihan seperti pernafasan, memahami dan mengenal nada, kemudian mengontrol nada, mengenal tempo, irama, artikulasi, diksi, penekanan pada kalimat, dan tentunya intonasi. Suara yang sudah bagus dan alami pun masih perlu dikembangkan bukan hanya untuk beryanyi, melainkan juga untuk berbicara (Stanislavski, 2008).

\section{Mengolah rasa}

Setelah persiapan atas tubuh dan vokal dari aktor itu sendiri sudah dilatihkan, maka tahap selanjutnya adalah mengolah rasa. Ini adalah hal abstrak yang banyak aktor gagal dalam mengolah rasanya. Setiap aktor mestilah melatih sukmanya agar selalu siap sedia kapan pun dibutuhkan ketika ia bermain. Teknik kerja batiniah yang kompleks ini dan jalan menuju kesadaran kreatif yang luar biasa adalah banyak dan berbeda-beda (Stanislavski, 2006)

\section{Observasi}

Tentu saja sebagai seorang penggiat dunia keaktoran, observasi sangatlah penting untuk perkembangan kemampuan keaktoran dari sang aktor itu sendiri. Observasi dalam hal ini bisa didapatkan dengan membaca beberapa buku tentang psikologi yang jelasjelas membahas tentang manusia secara dalam yang bisa sangat membantu dalam memahami sebuah tokoh. Selain itu observasi juga bisa didapatkan dengan menonton film, pertunjukan, dan mengunjungi ke beberapa tempat yang dirasa berhubungan dengan keadaan tokoh ini.

\section{Pembahasan dan Hasil Penelitian}

Di dalam naskah Terdampar karya Slawomir Mrozek ini, Sedang adalah salah satu tokoh yang memiliki dimensi yang cukup kompleks. Di dalam naskah ini, Sedang berbeda dengan dua tokoh utama yang lain yang memiliki porsi bicara yang cukup banyak. Sedang memiliki porsi bicara yang sedikit dengan banyak silent act.

Naskah Terdampar ini merupakan salah satu naskah absurd yang diciptakan oleh Slawomir Mrozek. Menurut Enoch Brater dalam artikel yang ia tulis yang berjudul The "Absurd" Actors in the Theatre of Samuel Beckett yang tergabung dalam jurnal pendidikan bertajuk The Educational Theatre Jurnal, mengatakan bahwa "For Camus, therefore, the figure of the actor serves a metaphorical function: within three hours he must experience and represent the entire course of "the dead-end path" the man in the audience". ("Bagi Camus, oleh karena itu, sosok aktor melayani fungsi metaforis : dalam waktu tiga jam ia harus mengalami dan mewakili jalannya seluruh "jalan buntu" dari tokoh tersebut dan menunjukkannya pada penonton") (Brater, 1975). 
Dari pernyataan di atas bisa disimpulkan bahwa penciptaan tokoh dalam naskah absurd mewajibkan sang aktor untuk memiliki fungsi metaforis. Untuk menuju fungsi metaforis, bisa dilakukan dengan banyak cara. Dalam hal ini aktor menggunakan metode dari Bertold Brecht untuk menciptakan tokohnya. Hal ini karena selain tokoh absurd mestilah memiliki fungsi metaforis, tokoh-tokoh di dalam naskah Terdampar ini juga tidak memiliki tiga dimensi yang utuh jika ditelaah dari dialognya. Maka penggunaan metode Brecht sebagai langkah awal untuk menciptakan tokoh Sedang ini merupakan langkah yang paling tepat. Selain itu, tokoh Sedang adalah tokoh kritik yang di dalamnya memiliki kandungan-kandungan kritik yang sengaja ditujukan pada golongan tertentu. Di dalam metode Brecht, seorang aktor dianjurkan untuk mampu melakukan kritik. Seperti dalam kutipan berikut;

"Jarak yang pasti antara aktor dan tokoh harus dibangun melalui gaya permainan. Aktor harus mampu melakukan kritik. Selanjutnya tentang laku tokoh, laku berikutnya harus terjadi di sana sehingga memungkinkan adanya pilihan dan kritik" (Mitter, 2002).

Dari kutipan di atas dapat disimpulkan bahwa aktor mesti mampu menciptakan jarak antara dirinya sendiri dan juga tokoh yang ia mainkan. Hal ini berguna sebagai bentuk penyadaran kepada penonton bahwa yang mereka lihat adalah sebuah pertunjukan drama. Seperti yang diinginkan Brecht di dalam konsep alienasinya.

Seorang aktor harus melakukan pengamatan dan penelitian. Pada mulanya, aktor adalah peneliti. Aktor harus mengamati dan meneliti berbagai aspek yang ada di lingkungan sekitarnya (Riantiarno, 2011). Dari kutipan di atas jelas bahwa seorang aktor mesti melakoni beberapa tahapan sebagai peneliti. Berikut adalah beberapa langkah yang dilalui aktor dalam menciptakan tokoh Sedang;

1. Bedah Naskah

Bedah naskah merupakan proses yang dilakukan setelah reading. Dalam proses ini bertujuan untuk semakin memperdalam pembedahan dari permukaan yang paling luar yang dihasilkan ketika reading.

Bedah naskah ini memberikan manfaat untuk mengetahui secara rigid soal tokoh Sedang. Meskipun pada akhirnya karena dialog tokoh ini yang sedikit dan dialog tokoh lain yang menyinggungnya juga sedikit, pencarian tokoh Sedang dilanjutkan pada pencarian persona yang sesuai dengan tokoh ini. Seperti yang sudah diutarakan di atas tadi bahwa tokoh ini adalah tokoh gagasan yang merupakan perwakilan dari suatu kaum. Pernyataan itu didapat setelah menelaan naskah secara dalam. Dari pernyataan itu kemudian penciptaan tokoh Sedang lebih berpusat pada persona yang ada di luar naskah tapi masih satu tema dengan naskah.

Bedah naskah tentu saja berdasar dari berbagai sudut pandang, mulai dari sudut pandang keilmuan ataupun berdasarkan tafsir dan obyek yang berada di luar dari naskah itu sendiri. Seperti yang sudah dipaparkan di atas bahwa naskah ini merupakan naskah gagasan. Hal tersebut telah dipaparkan pada Bab II dengan penjelasan yang terperinci.

\section{Blocking}

Blocking merupakan pengaturan posisi dan arah gerak aktor diatas panggung. Blocking yang baik haruslah seimbang, utuh, bervariasi dan memiliki titik pusat perhatian (point of interest) serta wajar dan tidak dibuat-buat. Dalam menciptakan blocking sutradara mempertimbangkan aspek ruang, aspek suasana, dan pengembangan karakter dengan memberikan motivasi yang kuat kepada aktor untuk bergerak. (Anirun, 1998). 
Tahapan ini merupakan tahapan yang dilakukan setelah melalui pembedahan naskah. Dalam tahapan ini sutradara mulai memberikan arahan yang pas untuk memenuhi ruang dengan garis yang tepat. Tugas aktor kemudian adalah menghidupkan garis yang diberikan itu dengan jiwa tokohnya.

Dalam proses ini, mulai bisa dilakukan dipraktekkan beberapa teknnik bermain. Salah satunya adalah penggunaan metode Brecht. Di dalam tahapan ini, training telah selesai, dan tokoh yang diciptakan sedikit banyak telah menemui bentuknya. Maka penggunaan metode Brecht dirasa paling tepat pada tahapan ini.

Brecht menuliskan salah satu metodenya di buku Shomit Mitter. Ia menginstruksikan "(i) Sebelum anda menyamakan atau menghilangkan diri anda dalam tokoh anda, pertama kali anda harus bersama-sama dengannya... (ii) Fase kedua adalah empati, pencarian bagi tokoh yang benar melalui rasa subjektif... menjadi satu dengannya... (iii) Dan kemudian fase ketiga anda mencoba melihat tokoh tersebut dari luar, dari sudut pandang masyarakat" (Mitter, 2002). Dalam tahap ini, fase ketiga bisa digunakan. Seperti yang Brecht bilang bahwa ia ingin aktornya memiliki kesadaran bahwa ia sedang memainkan tokoh dan mengkritiknya. Maka dengan menggunakan tahap ketiga ini akan memunculkan kesadaran aktor bahwa ia sedang memainkan tokoh.

Brecht menggunakan cara merekam para pemainnya yang sedang bermain dan kemudian setelah selesai mereka melihat permainan mereka sendiri. Selain berguna untuk menyadarkan bahwa mereka sedang memainkan tokoh, juga berguna untuk mengkoreksi diri sendiri atas apa yang dilakukan di atas panggung.

Selanjutnya, dalam tahapan ini pula, metode Brecht yang lain bisa digunakan.
Metode tersebut adalah metode berganti peran.

"Brecht menyarankan juga, bahwa aktor terkadang harus berganti peran dengan partner mereka sepanjang latihan. Apabila muncul bahaya dari para aktor yang berpegang teguh pada penemuan awal, dan secara tegas membangun adegan linier dalam perannya dengan mengabaikan semua dialektika, maka proses pergantian peran memiliki dampak alienasi yang bermanfaat berkat interpretasi aktor" (Mitter, 2002).

Dalam kutipan di atas Brecht menyarankan pergantian tokoh menjadi salah satu bentuk latihan untuk menyadarkan aktor bahwa ia sedang memainkan drama. Selain itu pergantian tokoh ini juga bisa berguna untuk menaikkan kesadaran aktor atas apa yang dilakukan lawan mainnya. Jika Stanislavsky menyarankan untuk memberi dan menerima, take and give, maka ini adalah salah satu cara untuk menyadarkan aktor untuk tahu seberapa porsi ketika memberi dan seberapa porsi ketika harus menerima dalam satu kesatuan permainan keaktoran.

Setelah menggunakan teknik Brecht, maka aktor pun mencoba teknk yang lain seperti teknik memasuki tokoh. Dalam setiap latihan, aktor selalu berusaha untuk mempersiapkan diri satu jam sebelum latihan dimulai. Selama satu jam tersebut, aktor mengisolasi dirinya di dalam bentuk tokoh Sedang dan melakukan aktivitas sehari-hari dengan bentuk tokoh Sedang. Hal ini dilakukan sebagai bentuk pembiasaan sehingga ketika bermain, teknik sudah terlampaui dan tokoh Sedang sudah menjadi milik si Aktor.

Selain itu, ketika sedang bermain di atas panggung, aktor mencoba untuk membaca situasi. Seperti yang diketahui di bab sebelumnya bahwa tokoh Sedang merupakan tokoh yang tidak banyak bicara, maka ia memiliki kesempatan luas untuk 
memperhatikan peristiwa. Setelah memperhatikan peristiwa tersebut, tokoh Sedang pun bisa merespon dan kemudian menggunakannya sebagai teknik untuk merangkai klimaks. Tokoh Sedang tidak boleh sedikit pun lengah terhadap peristiwa. Konsentrasi dibutuhkan secara utuh dalam memainkan tokoh Sedang.

\section{Run Throught.}

Run throught merupakan istilah yang sering digunakan untuk mengulang semua adegan dari awal sampai akhir tanpa cut. Istilah ini di ambil dari bahasa Inggris yakni run yang artinya berlari atau menjalankan, dan throught yang artinya dari awal sampai habis. Pada intinya, run throught adalah memulai adegan dari awal sampai akhir dan kemudian mengeveluasinya jika ada yang perlu dievaluasi.

Dalam tahapan ini aktor dituntut untuk terus berada pada posisi tokoh. Ia harus tetap konsisten pada posisinya sebagai tokoh. Hasil dari training dan beberapa metode yang dilakukan pada tahapan blocking, diuji cobakan secara utuh dalam satu waktu pertunjukkan pada bagian run throught.

Dalam tahapan ini, aktor menggunakan teknik masuk ke dalam tokoh dengan cara melakukan pemanasan, mengunci sakrum, lalu masuk dalam bentuk tubuh tokoh, membentuk wajahnya, menggunakan suara tokoh, dan menggunakan cara jalan tokoh. Hal ini harus dilakukan satu persatu karena menurut aktor sendiri, satu bentuk tokoh memancing bentuk lain dari tokoh tersebut. Dalam tokoh Sedang ini, yang menjadi perhatian aktor adalah bentuk mulutnya. Ketika aktor sudah membentuk mulutnya seperti mulut tokoh ciptaan aktor yakni Sedang, maka bentuk tubuh lain kemudian mengikuti.

\section{Simpulan}

Pada kenyataannya, ketika penulis memilih naskah Terdampar, ada beberapa hal yang tepat dipakai dalam naskah tersebut dan ada beberapa hal yang kurang tepat yang kemudian mencoba mencari jalan keluar dari masalah tersebut. Misalnya dalam pemilihan metode keaktoran Brecht dalam naskah Terdampar ini. Dalam pemilihan metode keaktoran, Brecht yang menjadi rujukan metode dan juga bentuk. Hal ini dikarenakan, dalam naskah absurd, bentuk keaktoran Brecht pun memungkinkan untuk digunakan sebagai rujukan bentuk dan metode.

Naskah Terdampar ini merupakan naskah yang sangat sulit untuk dimainkan. Selain karena naskah ini adalah naskah absurd, aktor juga harus bisa menjangkau pikiran Mrozek. Seperti yang diketahui bahwa aktor, sutradara, dan kawan-kawan yang terlibat dalam proses Terdampar kali ini dengan Slawomir Mrozek memiliki latar belakang yang jelas jauh berbeda. Begitu juga dengan pikiran dari penggarap dan pemilik naskah. Alhasil, dari jarak pikiran yang jauh tersebut, tim kreatif dari Terdampar ini kemudian mencoba untuk menebak jalan pikiran dari Slawomir Mrozek. Proses tersebut secara tidak langsung mendewasakan tim kreatif dan membuka wacana tim kreaatif menjadi lebih luas lagi.

Seperti yang sudah dikatakan di atas bahwa naskah Terdampar ini adalah sebuah naskah absurd. Permasalahan muncul lagi ketika naskah ini disejajarkan dengan konsep pertunjukan Brecht. Mereka akan menemui sebuah jalan buntu. Hal tersebut karena dalam konsep pertunjukan Brecht memiliki tujuan "menyadarkan" penonton tentang keadaan realita yang sesungguhnya. Sementara di dalam naskah Terdampar, ia tidak menunjukkan kesimpulan pada penonton. Tetapi dalam penggarapan pertunjukkan, di bagian akhir dan hampir di keseluruhan pertunjukan, diutarakan keadaan yang sedikit banyak memihak pada salah satu sisi. Dalam pertunjukan, Kurus 
terus-terusan ditindas hingga pada akhirnya ia menyerah pada ketertindasan itu dan kemudian memilih untuk menerima apa saja yang akan terjadi padanya. Dari kesimpulan di akhir pertunjukan tersebut, sudah terlihat bahwa bentuk dalam bentuk pertunjukkannya, kreator memilih untuk memihak.

Sementara dalam metode keaktorannya sendiri, seperti yang sudah dijelaskan sebelumnya, bahwa dalam pertunjukan absurd, aktor harus memiliki fungsi metaforis, maka penggunaan metode keaktoran Brecht sebagai metode pencarian keaktoran dirasa tepat. Hal itu karena di dalam Brecht sendiri, ada fungsi aktor yang harus mampu merubah, mengkritik, dan menghakimi tokoh. Dalam salah satu tiga fungsi tersebut, ada fungsi metaforis di dalamnya. Seperti yang diketahui, metaforis adalah fungsi yang muncul dari dua hal yang memiliki fungsi yang sama. Mengkritik, merubah, dan menghakimi tokoh terdapat dua fungsi sekaligus yakni fungsi aktor sebagai aktor, dan fungsi aktor sebagai tokoh. Maka penggunaan metode Brecht di dalam pertunjukan ini sangat tepat.

Dari proses diskusi yang panjang dan penemuan atas beberapa kesimpulan yang ada di dalam naskah Terdampar ini kemudian diputuskan untuk menggunakan metode keaktoran dari Brecht yang cukup lengkap. Brecht menggunakan metode Stanislavsky untuk sampai pada titik "tidak menjadi". Dari "tidak menjadi" kemudian bisa dilakukan pengkritikan, penghakiman, dan perubahan dalam diri tokoh tersebut.

Dalam perjalanan keaktoran selama proses Terdampar, aktor merasa perubahan yang signifikan dalam kualitas berakting. Sebagai contoh, tindakan untuk mengkritik, menghakimi dan merubah tokoh tidaklah sederhana. Meskipun cara yang paling sederhana adalah melepas tokoh itu begitu saja seperti apa yang dilakukan Firman sebagai tokoh Kurus ketika pertunjukan berlangsung. Tokoh Sedang tidak memiliki kesempatan itu. Tokoh ini harus melakukan penghakiman, pengkritikan, dan perubahan terhadap tokohnya ketika menjadi tokohnya sendiri. Kesempatan-kesempatan yang kecil itu yang kemudian membuat aktor banyak belajar. Secara garis besar, aktor berhasil melakukan hal tersebut karena pembacaan terhadap tokoh dan situasi yang berjalan terus selama pertunjukan.

Perjalanan keaktoran yang secara signifikan naik drastis ini juga tidak dirasakan oleh aktor yang memainkan tokoh Sedang saja. Aktor yang lain juga terlihat memiliki perkembangannya sendiri-sendiri. Tiara yang bermain sebagai tokoh Gendut yang notabene memiliki porsi yang banyak dan menjadi tulang punggung pertunjukan, mendapatkan tantangan yang besar. Tiara yang diawal proses memainkan tokoh Gendut dengan tersengal-sengal, seiring berjalannya proses Tiara mengalami perkembangan. Tiara menjadi lebih peka terhadap peristiwa, dimana pada awalnya Tiara terlalu sibuk dengan tokohnya sendiri. Selain itu Tiara juga menjadi lebih "dewasa" dalam proses keaktorannya. Hal tersebut terjadi karena benturan yang cukup banyak selama proses yang perlahan-lahan membentuk laku aktor yang tepat.

Sementara pada Firman yang selama studinya di ISI Yogyakarta sudah bermain di banyak pementasan, juga memiliki perkembangan yang signifikan. Firman yang dikenal memiliki tubuh dengan stamina yang bagus pun pada awalnya tersengalsengal di proses ini. Meskipun kemudian dari perjalanan proses yang dilalui membuat Firman belajar dan membuatnya berkembang ke arah yang lebih baik.

Sebagai seorang aktor, proses latihan dan pencarian tokoh adalah proses memahami diri dan memahami orang lain. Dalam proses tersebut juga terdapat proses menurunkan ego. Pengendalian ego sangat penting dalam menjalani sebuah proses 
kreatif yang kolektif. Hal tersebut karena di dalam proses, kepala yang muncul bukan hanya satu kepala, tapi beberapa kepala yang kemudian harus bisa saling mengerti satu sama lain. Sebagai seorang aktor, selain tanggung jawab untuk menyelesaikan pencarian tokohnya, tanggung jawab pada unsur lain juga harus diperhatikan dan dilakukan dengan tepat.

\section{Daftar Pustaka}

Anirun, S. (1998). Menjadi Aktor: "Pengantar Kepada Seni Peran Untuk Pentas dan Sinema”. Bandung: PT Rekamedia Multiprakarsa.

Brater, E. (1975). The 'Absurd' Actor in the Theatre of Samuel Beckett. Educational Theatre Jurnal, 27(2), 197-207. DOI: 10.2307/3206113.

Djohan. (2009). Psikologi Musik. Yogyakarta: Penerbit Best Publisher.

Mitter, S. (2002). Stanislavsky, Brecht, Grotowski, Brook Sistem Pelatihan Lakon. Yogyakarta: MSPI dan Arti.

Oida, Y. and Marshall, L. (2012). Ruang Tubuh Aktor. Surabaya: Dewan Kesenian Jawa Timur.

Riantiarno, N. (2011). Kitab Teater. Jakarta: Gramedia Widiasarana Indonesia.

Saptaria, R. E. (2006). Acting Handbook: Panduan Praktis Akting Untuk Film \& Teater. Bandung: Rekayasa Sains.

Soemanto, B. (2002). Godot di Amerika dan Indonesia, Suatu Studi Banding. Jakarta: PT Grasindo.

Stanislavski, C. (1981). Creating a Role. London: Methuen Drama.

Stanislavski, C. (2006). My Life In Art. Malang: Pustaka Kayu Tangan.

Stanislavski, C. (2008). Membangun Tokoh. Jakarta: Gramedia. 